\title{
Thyroid hormone receptor $\beta$-specific agonist GC-1 increases energy expenditure and prevents fat-mass accumulation in rats
}

\author{
Cássio M Villicev, Fatima R S Freitas, Marcelo S Aoki ${ }^{1}$, Cássio Taffarel ${ }^{2}$, Thomas S Scanlan ${ }^{3}$, \\ Anselmo S Moriscot ${ }^{4}$, Miriam O Ribeiro ${ }^{2}$, Antonio C Bianco ${ }^{5}$ and Cecília H A Gouveia \\ Department of Anatomy, Institute of Biomedical Sciences, University of Sao Paulo, Av. Prof Lineu Prestes, 2415 Sao Paulo 05508-900, Brazil \\ ${ }^{1}$ School of Arts, Sciences \& Humanities, University of Sao Paulo, Sao Paulo, Brazil \\ ${ }^{2}$ Department of Biosciences, Mackenzie Presbyterian University, Sao Paulo, Brazil \\ ${ }^{3}$ Departments of Pharmaceutical Chemistry \& Cellular and Molecular Pharmacology, University of California, San Francisco, California, USA \\ ${ }^{4}$ Department of Cell and Developmental Biology, Institute of Biomedical Sciences, University of Sao Paulo, SP, Brazil \\ ${ }^{5}$ Division of Endocrinology, Diabetes and Hypertension, Department of Medicine, Brigham and Women's Hospital and Harvard Medical School, Boston, \\ Massachusetts, USA \\ (Requests for offprints should be addressed to C H A Gouveia; Email: cgouveia@usp.br)
}

\begin{abstract}
It is well known that thyroid hormone affects body composition; however, the effect of the thyroid hormone receptor $\beta$ (TR $\beta$ )selective thyromimetic GC-1 on this biological feature had not been demonstrated. In the current study, we compared the effects of a 6-week treatment with triiodothyronine (T3; daily injections of 3 or $6 \mu \mathrm{g} / 100 \mathrm{~g}$ body weight) or GC-1 (equimolar doses) on different metabolic parameters in adult female rats. Whereas all animals gained weight $(17-25 \mathrm{~g})$ in a way not basically affected by T3 or GC-1 treatment, only T3 treatment selectively increased food intake (50-70\%). Oxygen consumption was significantly and equally increased (50-70\%) by T3 and GC-1. Analysis of body composition by dual-energy X-ray
\end{abstract}

absorptiometry (DEXA) revealed that, whereas control animals gained about $80 \%$ of fat mass, T3- or GC-1-treated animals lost $70-90$ and $\sim 20 \%$ respectively. Direct analysis of the carcass showed that T3 treatment promoted a $14-74 \%$ decrease in fat content but GC-1 treatment promoted only a $15-23 \%$ reduction. The gain in lean mass by DEXA and the carcass protein content were not affected by $\mathrm{T} 3$ or GC-1 treatment. However, the mass of individual skeletal muscles was negatively affected by $\mathrm{T} 3$ but only barely by $\mathrm{GC}-1$. These findings highlight the potential use of GC-1 for the treatment of obesity and the metabolic syndrome.

Journal of Endocrinology (2007) 193, 21-29

\section{Introduction}

Thyroid hormone controls gene expression by interacting with nuclear receptors (TRs), which are hormone-inducible transcriptional factors (Lazar 1993). Two genes encode TRs, $\operatorname{TR} \alpha$ and TR $\beta$ (Freedman 1992). At least two isoforms of $\operatorname{TR} \alpha$ and $\operatorname{TR} \beta$ have been identified and are the result of alternative splicing. TR $\alpha 1, T R \beta 1$ and TR $\beta 2$ isoforms bind $\mathrm{T} 3$, while TR $\alpha 2$ does not and functions, at least in vitro, as a TR $\alpha 1$ and TR $\beta 1$ antagonist (Katz \& Lazar 1993). Activation of TRs causes a multitude of physiological effects that range from actions on the embryonic development to actions on the maintenance of energy homeostasis in adults (Motomura \& Brent 1998).

It is fascinating that an excess of thyroid hormone can result in some therapeutically desirable effects, such as increased metabolic rate, lipolysis, cholesterol lowering, improvement of heart contractility and thyroid-stimulating hormone (TSH) suppression, which is beneficial in patients with thyroid cancer (Motomura \& Brent 1998). At the same time, systemic thyrotoxicosis also results in undesirable effects, including tachycardia, arrhythmia, muscle wasting, nervousness, fatigue and loss of bone mass (Motomura \& Brent 1998). A series of studies in mice with inactivation or mutation of different TR isoforms (Fowler et al. 1996, Fraichard et al. 1997, Johansson et al. 1998, Wikstrom et al. 1998, Gothe et al. 1999, Gauthier et al. 2001, Flamant et al. 2002), as well as studies in patients with the syndrome of resistance to thyroid hormone (characterised by mutations in TR $\beta$; Refetoff 2003, Cheng 2005), suggests that TR isoforms selectively mediate tissuespecific thyroid hormone responses. It is a general consensus that $\operatorname{TR} \alpha$ mediates the effects of thyroid hormone on the heart, while TR $\beta$ mediates its effects on plasma cholesterol and TSH secretion, some of the desirable effects of systemic thyrotoxicosis (Baxter et al. 2004). Therefore, the development of T3 analogues with preferred TR $\beta$ binding action could be a possible strategy of achieving desirable effects of T3 and bypassing the undesirable effects.

GC-1 is a synthetic analogue of thyroid hormone that is relatively selective for both binding and activation functions 
of TR $\beta 1$ over TR $\alpha 1$ (Chiellini et al. 1998). GC-1 has several structural differences with respect to the natural hormone T3, including replacement of the three iodine residues with methyl and isopropyl groups, of the biaryl ether linkage with a methylene linkage and of the amino acid side chain with an oxyacetic acid side chain (Chiellini et al. 1998). GC-1 binds TR $\beta 1$ with the same affinity as it does T3 but binds TR $\alpha 1$ with an affinity about ten times lower than that for T3. It is interesting that GC-1 presents selective actions in vitro (Chiellini et al. 1998) and in vivo (Trost et al. 2000, Ribeiro et al. 2001). The differential effects of GC-1 vs T3 on the thermogenesis by brown adipose tissue (Ribeiro et al. 2001), tadpole metamorphosis (Furlow et al. 2004) and the development of the bone and central nervous system (Morte et al. 2002, 2004, Manzano et al. 2003, Freitas et al. 2005) may be the result of GC- 1 selectivity for TR $\beta$. On the other hand, the selective effects of GC-1 may also be related to the body distribution of TR isoforms. In agreement with studies in which the TR $\beta$ gene has been disrupted (Johansson et al. 1999), GC-1 has almost no effects on the heart, which expresses mainly TR $\alpha 1$, but lowers serum levels of cholesterol and triglycerides, in agreement with a predominant expression of TR $\beta 1$ in the liver (Trost et al. 2000). Other studies also suggest that the selective actions of GC-1 might also be explained by differential tissue uptake since it presents clear tissue-specific accumulation (Trost et al. 2000, Baxter et al. 2004). It has been shown, for example, that GC-1 accumulates selectively in the liver as compared with the heart. The tissue/plasma ratio was similar for GC-1 and T3 in the liver but was 30 times lower in the heart (Trost et al. 2000).

It is well known that thyrotoxicosis affects body composition, reducing fat mass and lean mass (Lonn et al. 1998, Riis et al. 2005). In primates, treatment with GC-1 has been shown to increase oxygen consumption and to reduce body weight (Grover et al. 2004), but effects on body composition had not been determined yet. Here, we show that treatment with GC-1 increased the metabolic rate, had no effect on food intake and decreased fat mass while sparing the lean mass of rats. These data illustrate the potential of GC-1 as an agent for the treatment of metabolic disorders, including obesity.

\section{Materials and Methods}

\section{Animals and drugs}

All experimental procedures were performed in accordance with the guidelines of the Standing Committee on Animal Research of the University of Sao Paulo. Female Wistar rats were obtained from our breeding colony and maintained under controlled conditions of light and temperature $(12 \mathrm{~h}$ darkness: $12 \mathrm{~h}$ light cycle at $25^{\circ} \mathrm{C}$ ). All animals were kept in plastic cages, four per cage, and had free access to food (rat chow containing $1.4 \% \mathrm{Pi}, 0 \cdot 7 \% \mathrm{Ca}$ and $4.5 \mathrm{IU} / \mathrm{g}$ vitamin $\mathrm{D})$ and water. At the age of 100 days and a weight of $210-220 \mathrm{~g}$, the animals were randomly divided into five groups $(n=8$ per group): (i) control, treated with saline; (ii) $10 \times \mathrm{T} 3$, treated with $3 \mu \mathrm{g}$ T3/100 g body weight (BW) per day, which is equivalent to ten times the physiological dose of T3 (Bianco \& Silva 1987); (iii) $20 \times \mathrm{T} 3$, treated with double of the previous T3 dosage (6 $\mu \mathrm{g}$ T3/100 g body weight (BW) per day); (iv) 10xGC-1, treated with $1.5 \mu \mathrm{g} \mathrm{GC}-1 / 100 \mathrm{~g} \mathrm{BW}$ per day and (v) $20 \mathrm{xGC}-1$, treated with $3 \mu \mathrm{g} \mathrm{GC}-1 / 100 \mathrm{~g} \mathrm{BW}$ per day. The latter two groups were treated with $\mathrm{GC}-1$ in equimolar doses of $10 \times \mathrm{T} 3$ and $20 \times \mathrm{T} 3$ respectively. The equimolar doses of GC-1 were calculated from the molecular mass of T3 (mol mass $=651$ ) and GC-1 (mol mass=328.4). T3 (Sigma Chemicals) was dissolved in $40 \mathrm{mM} \mathrm{NaOH}$, and GC-1 was dissolved in dimethyl sulfoxide (DMSO) to a concentration of $1 \mathrm{mg} / \mathrm{ml}$; either T3 or GC-1 were then diluted in saline and administered i.p. every day for 6 weeks. BW was measured thrice a week (on Mondays, Wednesdays and Fridays). Body length (nose to base of the tail) was determined at the end of the experimental period.

\section{Serum parameters}

At the end of the experimental period, the animals were killed by decapitation and the blood of the trunk was collected. The serum was separated by centrifugation and immediately frozen. Total thyroxine (T4) and T3 serum levels were measured by commercial RIA kits (RIA-gnost T4 and RIAgnost T3, CIS Bio international, France). For the T4 and T3 assays, standard curves were constructed in our laboratory with a pool of charcoal-stripped rat serum. To determine whether GC-1 could cross-react in the T4 and T3 RIAs, we measured serum levels of $\mathrm{T} 4$ and $\mathrm{T} 3$ in hypothyroid rats treated with different doses of GC-1. Serum T4 was undetectable in all animals, and no differences were seen in serum levels of T3 between the GC-1-treated animals and the hypothyroid-untreated animals, indicating that $\mathrm{T} 4$ and $\mathrm{T} 3$ RIAs cannot detect GC-1.

\section{Food intake}

Once a week (weeks 1-6), the animals were individually maintained in metabolic cages for $24 \mathrm{~h}$ for determination of food intake. The rat chow $(60-70 \mathrm{~g})$ was weighed before (initial weight) and after (final weight) placing the animals in the metabolic cages for $24 \mathrm{~h}$. Food intake was calculated by the difference between the final and initial weight of the chow (food intake $=$ initial weight - final weight). A basal measurement was done 1 week before the initiation of T3 or GC-1 treatment (week 0).

\section{Determination of body composition by dual-energy X-ray absorptiometry (DEXA)}

Lean mass (LM) and fat mass (FM) were measured by dualenergy X-ray absorptiometry (DEXA) using the pDEXA 
Sabre Bone Densitometer and the pDEXA Sabre Software version 3.9.4 (Norland Medical Systems, Fort Atkinson, WI, USA), both specially designed for small animals. The research mode scan option was used for the measurements. Pixel spacing for the scan was set to $0.5 \times 1.0 \mathrm{~mm}$; the scan width to $10.5 \mathrm{~cm}$; the scan length to $11.5 \mathrm{~cm}$ and the scan speed to $8 \mathrm{~mm} / \mathrm{s}$. Since the scan window of the bone densitometer was not large enough to allow a total body scan of the rats used in this study, the scans were performed from the first lumbar vertebra to the hind limbs. This region was named hind body $(\mathrm{HB})$ in the present study. For the scans, the animals were anaesthetised with a cocktail of ketamine and xylazine (30 and $10 \mathrm{mg} / \mathrm{kg} \mathrm{BW}$ i.p. respectively) and scanned in the prone position. The animals were scanned before (basal scan) and after (final scan) 6 weeks of treatment. $\Delta \mathrm{LM}$ and $\Delta \mathrm{FM}$ were calculated, for each animal, by the difference between both scans (final scan-basal scan). For the scan analysis, the bone mineral density (BMD) histogram averaging width (BHAW) was set to $0.01 \mathrm{~g} / \mathrm{cm}^{2}$ for all scans. This parameter can be considered as a variable window that 'refines' the distribution of the scan data and allows the definition of the threshold for bone and soft tissues (LM and FM). To establish the appropriated BHAW to this study, we analysed scans of six rats. Two regions of interest (ROIs) were used: $\mathrm{HB}$ and soft tissue (ST), a ROI of $1 \mathrm{~cm}^{2}$ that included exclusively soft tissue. This ROI was placed $0.5 \mathrm{~cm}$ to the rear of the left femur and $0.5 \mathrm{~cm}$ to the left of the pelvis. BMD, LM and FM of $\mathrm{HB}$ and $\mathrm{ST}$ were measured using various BHAWs, ranging from 0.005 to $0 \cdot 2 \mathrm{~g} / \mathrm{cm}^{2}$. The values for each parameter were plotted and analysed. BMD and LM values increased and FM values decreased from the BHAW of $0 \cdot 005-0 \cdot 01 \mathrm{~g} / \mathrm{cm}^{2}$. From the BHAW of $0 \cdot 01-0 \cdot 2 \mathrm{~g} / \mathrm{cm}^{2}$, a plateau was established for each parameter. Thus, $0 \cdot 01 \mathrm{~g} / \mathrm{cm}^{2}$ was the BHAW of choice since it determined the first point in the plateau and allowed the greatest discrimination among BMD, FM and LM for all scans. The precision in vivo was evaluated by calculating the coefficient of variation $(\mathrm{CV}=100 \times$ S.D./mean) of six repeated measurements of a 2-month-old female rat weighing $207 \mathrm{~g}$. The animal was repositioned after each scan. The CV of LM and FM of the HB were 1.7 and $1.9 \%$ respectively. The precision in vitro was also expressed as $\mathrm{CV}$ and calculated by measuring the BMD of a phantom, with a nominal density of $0.929 \mathrm{~g} / \mathrm{cm}^{2}$. This $\mathrm{CV}$ was $0.8 \%$ throughout the experiment. The performance of the system was assessed and maintained by the quality assurance test (QA test), which includes scanner calibration and phantom scanning. The QA test was carried out on each day that scans were to be performed.

\section{Body composition by carcass analysis}

Carcasses were thawed overnight at $4{ }^{\circ} \mathrm{C}$, reweighed, cut in small pieces and then thoroughly homogenised with distilled water (the volume of water equals double the weight of the carcasses) in a blender (Kinematica AG., Lucerne,
Switzerland). Aliquots of homogenate were used for measurement of water, protein and fat content. The water content was determined according to the method of Bertin et al. (1998). Briefly, two aliquots of homogenate per animal were weighed before and after drying for $18 \mathrm{~h}$ in an oven at $103{ }^{\circ} \mathrm{C}$. Fat content was determined from triplicate aliquots of homogenate per animal according to Folch et al. (1957). Briefly, lipid was extracted from $0.3 \mathrm{~g}$ aliquots of homogenate with a 2:1 chloroform:methanol solution. The lipid-containing chloroform layer was separated and dried to a constant weight. The protein content was determined by the biuret method, as described by Brooks et al. (1995).

\section{Weight of fat pads, skeletal muscles and heart}

Immediately after animals were killed, the retroperitoneal fat pad, the heart and the quadriceps, gastrocnemius, soleus and extensor digitorum longus (EDL) were carefully dissected out and weighed (wet weight). The samples of the skeletal muscles were then transferred to an incubator at $60{ }^{\circ} \mathrm{C}$ for $48 \mathrm{~h}$ and weighed again (dry weight). The water content of each sample was determined by the difference between the wet and dry weights (water content $=$ wet weight - dry weight). All weights were expressed in $\mathrm{mg} / \mathrm{g} \mathrm{BW}$.

\section{Oxygen consumption}

Resting oxygen consumption $\left(\mathrm{VO}_{2}\right)$ was measured in conscious rats in an open-circuit respirometer system (S-3A/1, Ametek, Pittsburgh, PA, USA) as previously described (Withers 1977) at the end of the experimental period. All measurements were carried out at room temperature $\left(>25^{\circ} \mathrm{C}\right)$ over a period of $1 \mathrm{~h}$ during the morning (0900-1200 h). Animals were studied while they were in the fed condition and were maintained under normal experimental conditions until immediately before the measurements were taken. Online data were collected and analysed with a computer system running on DataCan V software (Sable Systems, Salt Lake City, UT, USA). Results were corrected for environmental temperature and atmospheric pressure and expressed in terms of microlitres of $\mathrm{O}_{2}$ per min/g BW.

\section{Statistical analysis}

One-way ANOVA was used to compare more than two groups and was always followed by the Student-NewmanKeuls test to detect differences between groups. For all tests, $P<0 \cdot 05$ was considered statistically significant. All results are expressed as the mean \pm s.E.M. For statistical analysis, we used the GraphPad Instat Software (GraphPad Software, San Diego, CA, USA). 
Table 1 Serum levels (ng/ml) of T3 and T4. Values are the means \pm S.E.M. $(n=8$ for all groups)

\begin{tabular}{|c|c|c|}
\hline & T3 & T4 \\
\hline \multicolumn{3}{|l|}{ Group } \\
\hline Control & $1 \cdot 02 \pm 0 \cdot 2$ & $48 \cdot 0 \pm 2 \cdot 7$ \\
\hline $10 \times \mathrm{T} 3$ & $>2$ & $30 \cdot 2 \pm 1 \cdot 2 *$ \\
\hline $20 \times \mathrm{T} 3$ & $>2$ & $31 \cdot 9 \pm 3^{*}$ \\
\hline $10 \times \mathrm{GC}-1$ & $0 \cdot 80 \pm 0 \cdot 07$ & $46 \cdot 7 \pm 1 \cdot 3$ \\
\hline $20 \times$ GC -1 & $0.84 \pm 0.09$ & $32 \cdot 9 \pm 2 \cdot 9^{*}$ \\
\hline
\end{tabular}

Significance among groups was determined by ANOVA followed by Student-Newman-Keuls test. $* P<0.001$ vs control.

\section{Results}

Serum levels of T3 and T4

As expected, serum levels of T3 were significantly higher in the $10 \times \mathrm{T} 3$ - and $20 \times \mathrm{T} 3$-treated groups than in the controls (Table 1). Serum levels of T3 were not affected by treatment with GC-1. On the other hand, serum levels of T4 were lower in the $10 \times \mathrm{T} 3-, 20 \times \mathrm{T} 3-$ and $20 \times \mathrm{GC}-1-$ treated animals than in the controls.

\section{Effects of T3 and GC-1 on body weight and food intake}

Body weight was barely affected by $\mathrm{T} 3$ and was not affected by GC-1 (Fig. $1 \mathrm{~A}$ and B). Both $10 \times \mathrm{T} 3$ and $20 \times \mathrm{T} 3$ treatments reduced body weight by approximately 6 and $10 \%$ when compared with controls $(P<0 \cdot 05$ for both) respectively, from day 6 to day 10 of treatment. Rats treated with $20 \times \mathrm{T} 3$ also presented with a lower body weight than control rats $(-7 \cdot 4 \%, P<0 \cdot 05)$ from day 24 to day 27 of treatment, but by the end of the treatment period, all animals were the same body weight. The body length was not affected by T3 or $\mathrm{GC}-1$.

Treatments with $10 \times \mathrm{T} 3$ and $20 \times \mathrm{T} 3$ increased food intake by 50 and $72 \%(P<0.001$ for both vs controls $)$ respectively, in week 2 of treatment, while treatment with GC-1 had no effect on food intake (Fig. 1C). Food intake in the T3-treated animals remained $\approx 63 \%$ greater than that in controls until the end of the treatment period.

\section{Effects of T3 and GC-1 on oxygen consumption}

At the end of the experimental period, resting oxygen consumption $\left(\mathrm{VO}_{2}\right)$ was significantly and equally increased by treatment with $\mathrm{T} 3$ or $\mathrm{GC}-1$ by about $46-88 \%$ when compared with that of controls (Fig. 2).

\section{Effects of T3 and GC-1 on fat mass and fat content}

Analysis of body composition by DEXA showed that treatment with $\mathrm{T} 3$ or GC-1 negatively affected $\Delta \mathrm{FM}$ (Fig. 3A). While control rats presented an increase of
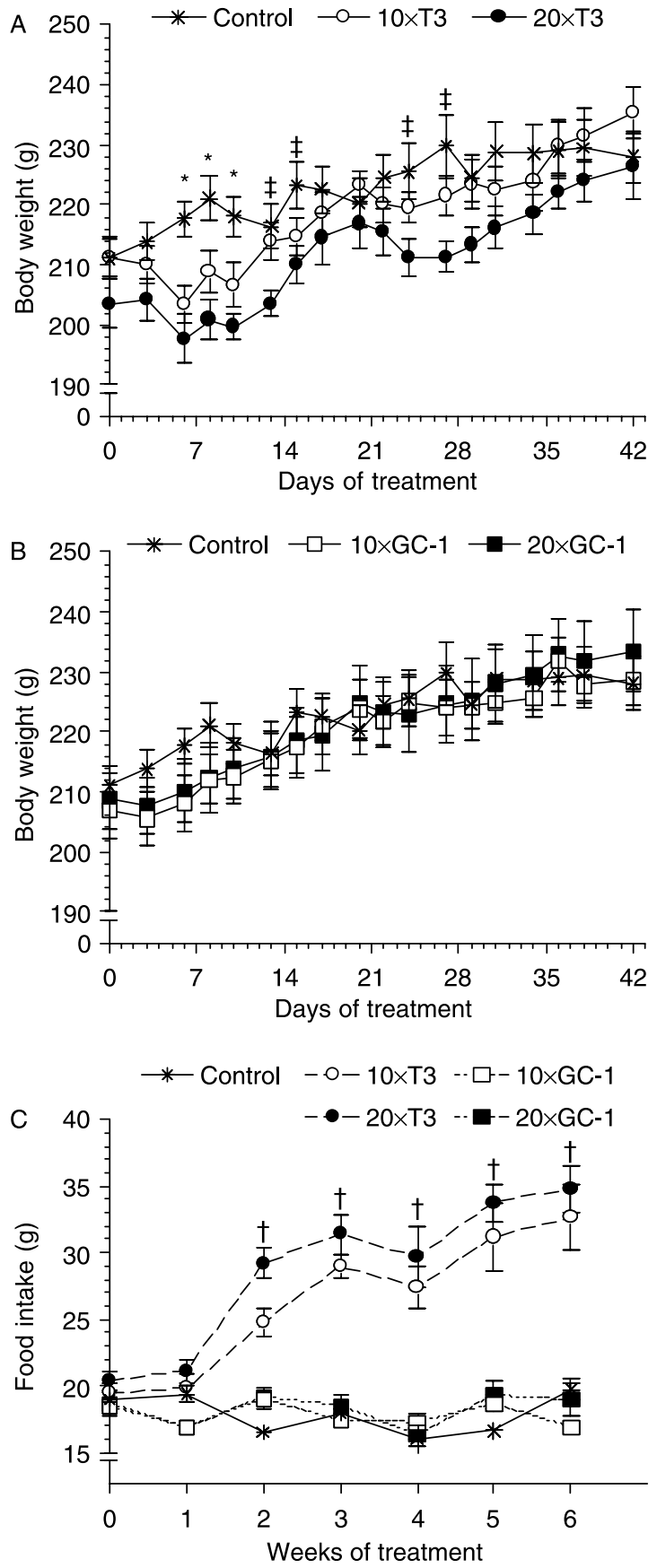

Figure 1 Effects of T3 and GC-1 on body weight and food intake. (A) Body-weight response to treatment with T3. (B) Body-weight response to treatment with GC-1. Body weight was measured thrice a week in control rats and rats treated for 6 weeks with T3 or GC-1. (C) Food intake was determined weekly in control rats and rats treated for 6 weeks with T3 or GC-1. All values (A-C) are expressed as the mean \pm S.E.M. $\left(n=8\right.$ per group). $* P<0 \cdot 05$ and ${ }^{\dagger} P<0 \cdot 001$, control vs $10 \times \mathrm{T} 3$ and $20 \times \mathrm{T} 3$ and ${ }^{\ddagger} P<0 \cdot 05$, control vs $20 \times \mathrm{T} 3$ by Student-Newman-Keuls test. 


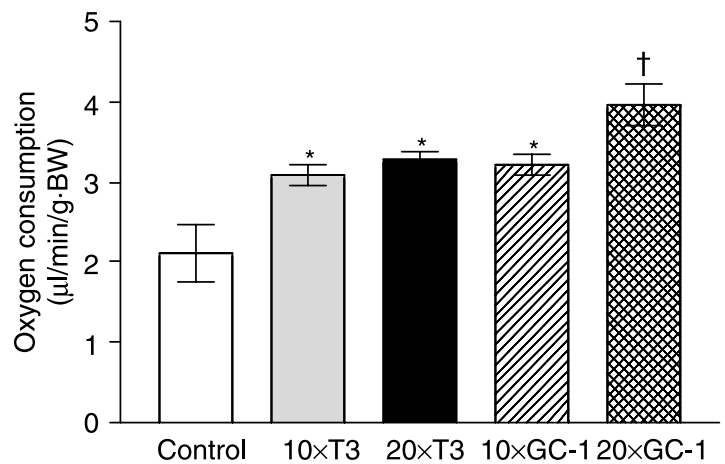

Figure 2 Effects of T3 and GC-1 on oxygen consumption. Resting oxygen consumption was measured at the end of the experimental period in control rats and rats treated for 6 weeks with T3 or GC-1. All values are expressed as the mean \pm s.E.M. $(n=5$ per group). ${ }^{*} P<0.01$ and ${ }^{\dagger} P<0.001$ vs control by Student-NewmanKeuls test.

approximately $83 \%(6.5 \mathrm{~g})$ in fat mass, $10 \times \mathrm{T} 3$ - and $20 \times \mathrm{T} 3$ treated rats lost approximately $74 \%(4 \cdot 2 \mathrm{~g})$ and $91 \%(5 \cdot 9 \mathrm{~g})$ respectively, of their fat mass. Treatment with $10 \times$ GC- 1 resulted in a gain of fat mass of only $21 \%(1.7 \mathrm{~g})$, and treatment with $20 \times \mathrm{GC}-1$ induced a decrease in fat mass of $20 \%(1 \cdot 3 \mathrm{~g})$.

The determination of fat content by analysis of the carcass showed that $10 \times \mathrm{T} 3,20 \times \mathrm{T} 3,10 \times \mathrm{GC}-1$ and $20 \times \mathrm{GC}-1$ significantly reduced the fat content by $14,74,15$ and $23 \%$ respectively, when compared with controls (Fig. 3B). Treatment with $10 \times \mathrm{T} 3,20 \times \mathrm{T} 3$ and $20 \times \mathrm{GC}-1$ significantly reduced the mass of the retroperitoneal fat pad by 68 , 73 and $48 \%$ respectively (Fig. 3 C).

Effects of T3 and GC-1 on lean mass, protein content, skeletal muscle mass and heart mass

Treatment with T3 or GC-1 did not affect $\Delta \mathrm{LM}$, as determined by DEXA, and the protein content, as determined by carcass analysis. Nevertheless, skeletal muscle mass was negatively affected by T3 (Table 2 ). The wet and dry masses of the quadriceps, gastrocnemius and soleus of the T3treated animals were significantly lower (13-36\%) than those of the control animals, while these parameters were not affected in the EDL muscle. Treatment with $20 \times$ GC- 1 significantly reduced wet and dry masses of the quadriceps by 16 and $24 \%$ respectively. None of the other skeletal muscles were affected by GC-1. The wet mass of the quadriceps increased $15 \%(P<0 \cdot 01$ vs control) after treatment with $10 \times$ GC-1, which can be explained by an increase in its water content $(19 \%$ vs control, $P<0 \cdot 001)$. As expected, treatment with $10 \times \mathrm{T} 3$ or $20 \times \mathrm{T} 3$ resulted in cardiac hypertrophy, characterised by an increase in the dry mass of the heart $(33$ and $46 \%$ vs control respectively), while GC- 1 treatment had no effect.
A

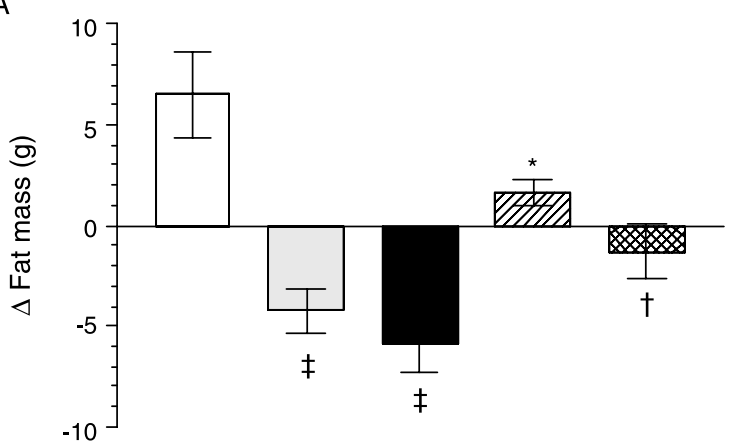

B

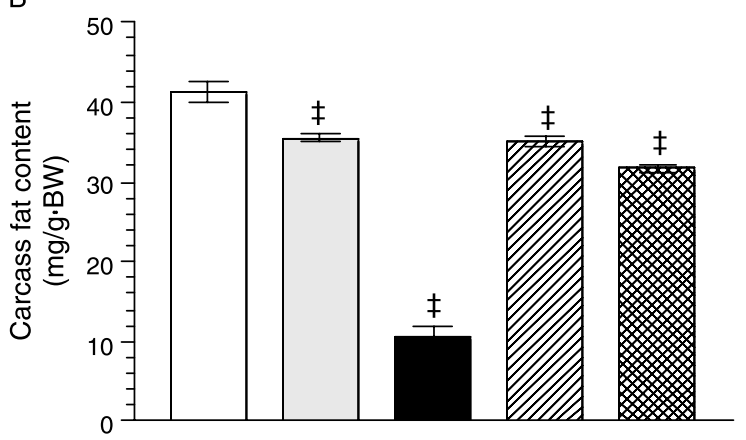

C

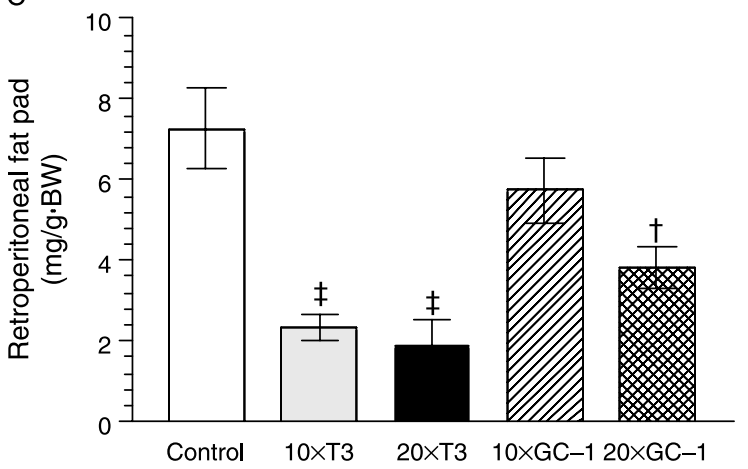

Figure 3 Effects of T3 and GC- 1 on change in fat mass, carcass fat content and retroperitoneal fat pad. All parameters were determined in control rats and rats treated for 6 weeks with T3 or GC-1. (A) $\Delta$ Fat mass (final fat mass-basal fat mass) was determined in vivo by DEXA. (B) Carcass fat content. (C) Retroperitoneal fat pad. All values are expressed as the mean \pm S.E.M. $(n=8$ per group). ${ }^{*} P<0 \cdot 05,{ }^{\dagger} P<0 \cdot 01$ and ${ }^{\ddagger} P<0 \cdot 001$ vs control by StudentNewman-Keuls test.

\section{Discussion}

The present study shows that treatment with GC-1 increases $\mathrm{VO}_{2}$ (Fig. 2), a finding corroborated by a previous report (Grover et al. 2004). It is interesting however that $10 \times \mathrm{GC}-1$ and $20 \times \mathrm{GC}-1$ increased $\mathrm{VO}_{2}$ by 53 and $90 \%$ respectively, whereas Grover et al. (2004) observed only modest (5-10\%) increases in $\mathrm{VO}_{2}$ with doses of GC-1 in this range. Such a discrepancy might be explained by the much longer duration of GC-1 treatment in the current investigation (1 vs 6 weeks). 
Table 2 Effects of T3 and GC-1 on skeletal mass and heart mass

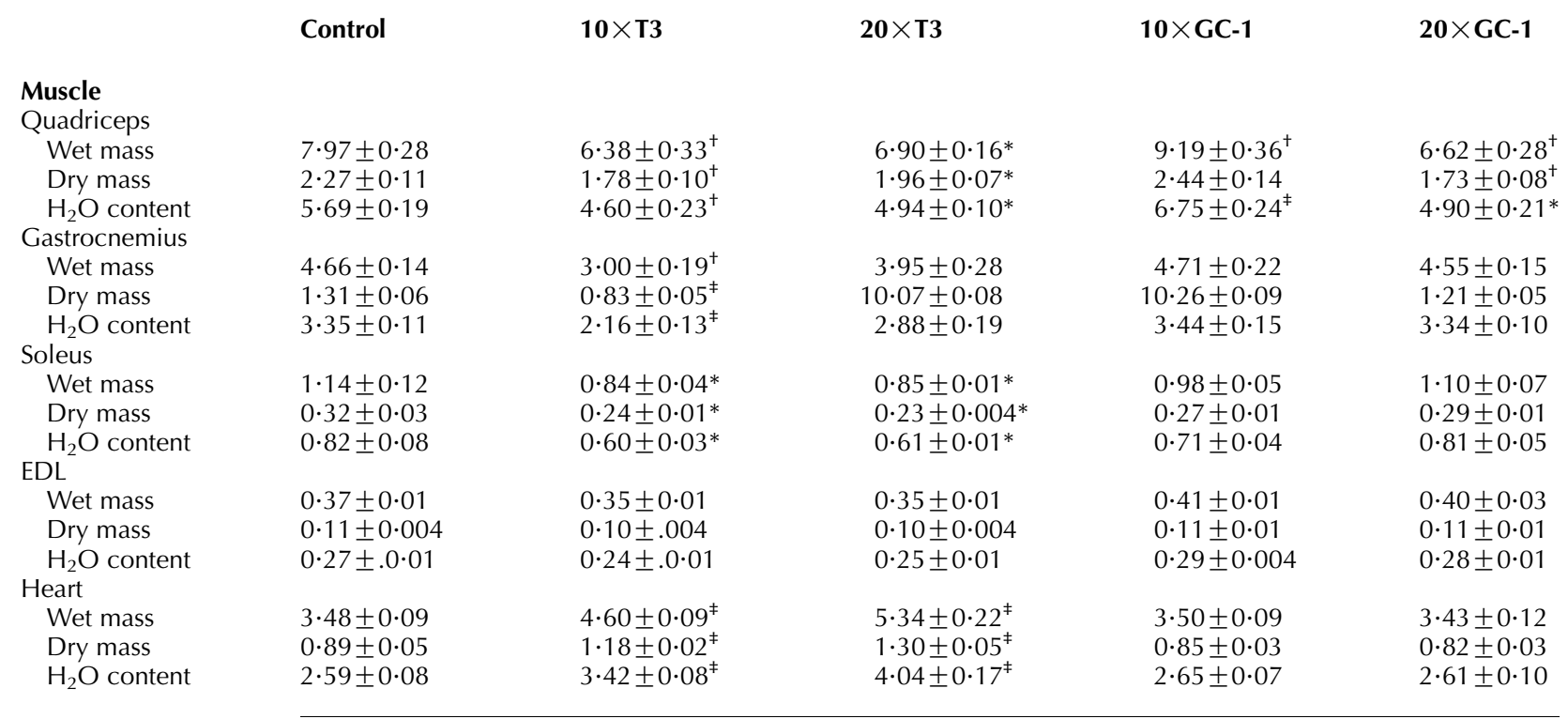

Wet mass and dry mass are expressed as $\mathrm{mg} / \mathrm{g}$ BW and $\mathrm{H}_{2} \mathrm{O}$ content as $\mu \mathrm{l} / \mathrm{g}$ BW. Values are the mean \pm s.E.M. ( $n=8$ for all groups). Significance among groups was determined by ANOVA followed by Student-Newman-Keuls test. ${ }^{*} P<0 \cdot 01$ vs control. ${ }^{+} P<0 \cdot 05$ vs control. ${ }^{\ddagger} P<0 \cdot 001$ vs control.

In addition, other differences between these studies may have accounted for some of the variation in oxygen consumption, such as gender (male vs female), strain of rats (SpragueDawley vs Wistar), the route of ligand administration (gavage vs i.p. injection) and diet (cholesterol-fed rats vs regular-fed rats). An important and original finding of the present investigation was that the GC-1-induced increase in $\mathrm{VO}_{2}$ was not accompanied by an increase in food intake (Fig. 1C) but led to a $20 \%$ reduction in body fat content (Fig. 3A-C) without substantially affecting lean or skeletal muscle mass (Table 2).

It is well known that thyroid hormone promotes lipolysis (Wahrenberg et al. 1994). In the present study, DEXA analysis showed that animals treated with $10 \times \mathrm{T} 3$ and $20 \times \mathrm{T} 3$ presented with a decrease in fat mass of approximately 74 and $91 \%$, while control animals gained fat mass (Fig. 3A). This finding is in agreement with the data from carcass analysis of body composition. The treatments with $10 \times \mathrm{T} 3$ and $20 \times \mathrm{T} 3$ reduced the fat content of the animals by 14 and $74 \%$ respectively (Fig. 3B). It is noteworthy that GC-1 also decreased the fat mass. The animals treated with $10 \times \mathrm{GC}-1$ gained significantly less fat mass than did controls, and rats treated with $20 \times \mathrm{GC}-1$ lost approximately $20 \%$ of their fat mass (Fig. 3A). The carcass analysis showed that $10 \times \mathrm{GC}-1$ and $20 \times \mathrm{GC}-1$ reduced the fat content by 15 and $23 \%$ respectively, when compared with control animals (Fig. 3B), an effect that was less pronounced than that of T3. This could be explained by a lower uptake of GC-1 by the adipose tissue when compared with the uptake of T3 (Trost et al. 2000). In view of the recognised stimulatory effect of thyroid hormone on lipolysis (Moller et al. 1996), it is predictable that the reducing effect of GC-1 on fat mass shown in the present study was a consequence of an increase in lipolysis and not of a reduction in lipogenesis. Indeed, Ribeiro et al. (2001) showed that equimolar doses of T3 or GC-1 equally increased the mRNA expression of malic enzyme, an important NADPH-generating lipogenic enzyme, in the livers of mice, suggesting that GC-1, like T3, increases lipogenesis.

It is known that thyroid status strongly influences the contractile function and the mass of the skeletal muscle. However, by DEXA, we could not detect alterations in lean mass induced by $\mathrm{T} 3$ or GC-1. These results could be explained by a limited sensitivity of this method of body composition analysis in small animals. In addition, it is important to consider that lean mass by DEXA is determined by the content of minerals that are not from bone, proteins, water and glycogen. As a consequence, changes in these body components, or even the absence of alterations, may mask small or moderate changes in the skeletal muscle mass. In fact, in the present study, the effects of T3 excess on the skeletal muscle were compatible with those described in the literature (White et al. 2001). We showed that the quadriceps, gastrocnemius and soleus of animals treated with T3 present lower mass than do those of the control group (Table 2). The EDL mass however was not affected by T3 excess. This corroborates a series of studies that showed that this muscle is weakly responsive to the thyroid status in relation to protein metabolism (Angeras \& Hasselgren 1985), muscular function (Nicol \& Bruce 1981), the expression of genes related to their function (dos Santos et al. 2001) and histological modifications (Devor \& White 1995, dos Santos et al. 2001). In the present study, we showed that the mass of all skeletal muscles, 
except for the quadriceps, was not decreased by GC-1 (Table 2). It is interesting that GC-24, a TR $\beta$-selective compound similar to GC-1, mostly spares skeletal muscle from changes in fibre type and tropism induced by T3 (Miyabara et al. 2005). The predominance of TR $\alpha$ over TR $\beta$ (White et al. 2001) and/or the poorer penetration of GC-1 in the skeletal muscle (Trost et al. 2000), compared with T3, may explain in part the minimal effects of these TR $\beta$-selective compounds on this tissue.

In addition to evaluating the effect of $\mathrm{T} 3$ or GC-1 on skeletal muscle, we evaluated the effect of these agents on cardiac muscle mass. This analysis was done to obtain positive and negative controls for the treatment with T3 or GC-1 respectively. It is well known that an excess in thyroid hormone causes cardiac hypertrophy (Danzi \& Klein 2004) and that GC-1 does not modify the cardiac mass and function (Trost et al. 2000). As expected, T3, but not GC-1, increased the heart mass (Table 2), which is a good positive control for the ability of the doses of T3 used in the present study to promote thyrotoxicosis.

We also found that body weight was barely affected by T3 treatment and, different from what has been shown in primates (Grover et al. 2004), body weight was not affected by GC-1. T3treated animals presented a body weight that was lower than that of controls only from day 6 to day 9 and from day 24 to day 27 of treatment (Fig. 1A and B). The absence or minimal effects of T3 on body weight of rats were noticed previously (Yu et al. 1998, Soukup et al. 2001). In the present study, it can be explained by the increase in food intake induced by T3 (Fig. 1C). On the other hand, GC-1 had no effect on energy ingestion, despite an increase in oxygen consumption at the same magnitude as that with T3 (Fig. 2). The increase in food intake is characteristic of hyperthyroidism. It is believed that one of the mechanisms by which T3 increases food intake involves the progressive depletion of fat stocks, a signal known to regulate the ingestion of energy (Iossa et al. 2001). However, T3 was recently shown also to stimulate food intake directly, through the hypothalamic ventromedial nucleus and independently of modifications in energy consumption (Kong et al. 2004). Considering the selectivity of GC- 1 for TR $\beta$ and that this T3 analogue increased oxygen consumption, reduced the body fat content, but did not affect food intake, our data suggest that the direct effect of T3 on energy ingestion is essential and likely to be mediated by TR $\alpha$ in rats. Another point to be considered is the lack of effect of GC-1 on body weight (Fig. 1B), which is unusual with regard to energy balance since it increased $\mathrm{VO}_{2}$ without increasing energy ingestion. The unchanged body weight is possibly explained by the fact that GC-1 significantly reduced body fat content and barely affected muscle mass.

As pointed out before, the TR $\beta$ selectivity of GC-1 may partially explain some effects of GC-1 observed in the present investigation. If this assumption is true, we could consider that $\operatorname{TR} \beta$ mediates T3 actions that decrease fat mass and increase $\mathrm{VO}_{2}$, whereas TR $\alpha$ mediates T3 actions that decrease muscle mass and increase food intake. However, GC-1 presents other properties that must be considered and that may contribute to its selective effects. The selective tissue uptake of GC- 1 is an important point, as mentioned before; there is a lower uptake of GC- 1 by the skeletal muscle and adipose tissue than of T3 (Trost et al. 2000). In addition, a recent in vitro study showed that GC-1 behaves largely as a T3 agonist but recruits coactivators or corepressors on some thyroid hormone response elements differently and does this independently of the TR isoform (Gloss et al. 2005). The functional consequence of these observations would be a differential regulation of some genes by GC- 1 vs $\mathrm{T} 3$ that is independent of the GC- 1 selectivity for TR $\beta$. It seems therefore that the mechanisms underlying the differential effects of GC-1 vs T3 on the biological systems, including body composition, depend on a series of different properties of these ligands, besides the TR $\beta$ selectivity of $\mathrm{GC}-1$, which remains to be further investigated.

In conclusion, this is the first study showing that treatment with GC-1 decreases the body content of adipose tissue while it does not increase food intake and barely affects the mass of skeletal muscle. The reduction of body fat content added to other GC-1 effects previously described, such as reduction of serum levels of cholesterol, triglycerides and TSH (Trost $e t$ al. 2000, Freitas et al. 2003, Grover et al. 2004), and the lack of deleterious effects of GC-1 on the heart structure and function (Trost et al. 2000), skeletal muscle mass and bone mass (Freitas et al. 2003) suggest that GC-1 has the potential to be used as a therapeutic agent for a variety of disorders, such as obesity, hyperlipidaemia and hypercholesterolaemia.

\section{Acknowledgements}

The authors are grateful to Dr Patrícia C Brum, from the Physical Education and Sports School, University of Sao Paulo, Brazil, for essential contributions in the $\mathrm{VO}_{2}$ measurements.

\section{Funding}

This work was supported by a grant (process \# 05/52910-4) from Fundação de Amparo à Pesquisa do Estado de São Paulo, Brazil (C H A Gouveia). The authors declare that there is no conflict of interest that would prejudice the impartiality of this scientific work.

\section{References}

Angeras U \& Hasselgren PO 1985 Protein turnover in different types of skeletal muscle during experimental hyperthyroidism in rats. Acta Endocrinologica 109 90-95.

Baxter JD, Webb P, Grover G \& Scanlan TS 2004 Selective activation of thyroid hormone signaling pathways by GC-1: a new approach to controlling cholesterol and body weight. Trends in Endocrinology and Metabolism 15 154-157.

Bertin E, Ruiz JC, Mourot J, Peiniau P \& Portha B 1998 Evaluation of dualenergy X-ray absorptiometry for body-composition assessment in rats. Journal of Nutrition 128 1550-1554. 
Bianco AC \& Silva JE 1987 Nuclear 3,5,3'-triiodothyronine (T3) in brown adipose tissue: receptor occupancy and sources of $\mathrm{T} 3$ as determined by in vivo techniques. Endocrinology 120 55-62.

Brooks SP, Lampi BJ, Sarwar G \& Botting HG 1995 A comparison of methods for determining total body protein. Analytical Biochemistry 226 26-30.

Cheng SY 2005 Thyroid hormone receptor mutations and disease: beyond thyroid hormone resistance. Trends in Endocrinology and Metabolism 16 176-182.

Chiellini G, Apriletti JW, Yoshihara HA, Baxter JD, Ribeiro RC \& Scanlan TS 1998 A high-affinity subtype-selective agonist ligand for the thyroid hormone receptor. Chemistry and Biology 5 299-306.

Danzi S \& Klein I 2004 Thyroid hormone and the cardiovascular system. Minerva Endocrinologica 29 139-150.

Devor ST \& White TP 1995 Myosin heavy chain phenotype in regenerating skeletal muscle is affected by thyroid hormone. Medicine and Science in Sports and Exercise 27 674-681.

Flamant F, Poguet AL, Plateroti M, Chassande O, Gauthier K, Streichenberger N, Mansouri A \& Samarut J 2002 Congenital hypothyroid Pax8(-/ - ) mutant mice can be rescued by inactivating the TRalpha gene. Molecular Endocrinology 16 24-32.

Folch J, Lees M \& Sloane Stanley GH 1957 A simple method for the isolation and purification of total lipids from animal tissues. Journal of Biological Chemistry 226 497-509.

Fowler PB, McIvor J, Sykes L \& Macrae KD 1996 The effect of long-term thyroxine on bone mineral density and serum cholesterol. Journal of the Royal College of Physicians of London 30 527-532.

Fraichard A, Chassande O, Plateroti M, Roux JP, Trouillas J, Dehay C, Legrand C, Gauthier K, Kedinger M, Malaval L et al. 1997 The T3R alpha gene encoding a thyroid hormone receptor is essential for post-natal development and thyroid hormone production. EMBO Journal 16 4412-4420.

Freedman LP 1992 Anatomy of the steroid receptor zinc finger region. Endocrine Reviews 13 129-145.

Freitas FR, Moriscot AS, Jorgetti V, Soares AG, Passarelli M, Scanlan TS, Brent GA, Bianco AC \& Gouveia CH 2003 Spared bone mass in rats treated with thyroid hormone receptor TR $\beta$-selective compound GC-1. American Journal of Physiology. Endocrinology and Metabolism 285 E1135-E1141.

Freitas FR, Capelo LP, O'Shea PJ, Jorgetti V, Moriscot AS, Scanlan TS, Williams GR, Zorn TM \& Gouveia CH 2005 The thyroid hormone receptor beta-specific agonist GC-1 selectively affects the bone development of hypothyroid rats. Journal of Bone and Mineral Research 20 294-304.

Furlow JD, Yang HY, Hsu M, Lim W, Ermio DJ, Chiellini G \& Scanlan TS 2004 Induction of larval tissue resorption in Xenopus laevis tadpoles by the thyroid hormone receptor agonist GC-1. Journal of Biological Chemistry 279 26555-26562.

Gauthier K, Plateroti M, Harvey CB, Williams GR, Weiss RE, Refetoff S, Willott JF, Sundin V, Roux JP, Malaval L et al. 2001 Genetic analysis reveals different functions for the products of the thyroid hormone receptor alpha locus. Molecular and Cellular Biology 21 4748-4760.

Gloss B, Giannocco G, Swanson EA, Moriscot AS, Chiellini G, Scanlan T, Baxter JD \& Dillmann WH 2005 Different configurations of specific thyroid hormone response elements mediate opposite effects of thyroid hormone and GC-1 on gene expression. Endocrinology 146 4926-4933.

Gothe S, Wang Z, Ng L, Kindblom JM, Barros AC, Ohlsson C, Vennstrom B \& Forrest D 1999 Mice devoid of all known thyroid hormone receptors are viable but exhibit disorders of the pituitary-thyroid axis, growth, and bone maturation. Genes and Development 13 1329-1341.

Grover GJ, Egan DM, Sleph PG, Beehler BC, Chiellini G, Nguyen NH, Baxter JD \& Scanlan TS 2004 Effects of the thyroid hormone receptor agonist GC-1 on metabolic rate and cholesterol in rats and primates: selective actions relative to $3,5,3^{\prime}$-triiodo-L-thyronine. Endocrinology 145 1656-1661

Iossa S, Lionetti L, Mollica MP, Crescenzo R, Barletta A \& Liverini G 2001 Fat balance and serum leptin concentrations in normal, hypothyroid, and hyperthyroid rats. International Journal of Obesity and Related Metabolic Disorders 25 417-425.

Johansson C, Vennstrom B \& Thoren P 1998 Evidence that decreased heart rate in thyroid hormone receptor-alpha1-deficient mice is an intrinsic defect. American Journal of Physiology 275 R640-R646.
Johansson C, Gothe S, Forrest D, Vennstrom B \& Thoren P 1999 Cardiovascular phenotype and temperature control in mice lacking thyroid hormone receptor-beta or both alpha1 and beta. American Journal of Physiology 276 H2006-H2012.

Katz D \& Lazar MA 1993 Dominant negative activity of an endogenous thyroid hormone receptor variant (alpha 2) is due to competition for binding sites on target genes. Journal of Biological Chemistry 268 20904-20910.

Kong WM, Martin NM, Smith KL, Gardiner JV, Connoley IP, Stephens DA, Dhillo WS, Ghatei MA, Small CJ \& Bloom SR 2004 Triiodothyronine stimulates food intake via the hypothalamic ventromedial nucleus independent of changes in energy expenditure. Endocrinology 145 5252-5258.

Lazar MA 1993 Thyroid hormone receptors: multiple forms, multiple possibilities. Endocrine Reviews 14 184-193.

Lonn L, Stenlof K, Ottosson M, Lindroos AK, Nystrom E \& Sjostrom L 1998 Body weight and body composition changes after treatment of hyperthyroidism. Journal of Clinical Endocrinology and Metabolism 83 4269-4273.

Manzano J, Morte B, Scanlan TS \& Bernal J 2003 Differential effects of triiodothyronine and the thyroid hormone receptor beta-specific agonist GC1 on thyroid hormone target genes in the brain. Endocrinology 144 5480-5487.

Miyabara EH, Aoki MS, Soares AG, Saltao RM, Vilicev CM, Passarelli M, Scanlan TS, Gouveia CH \& Moriscot AS 2005 Thyroid hormone receptorbeta-selective agonist GC-24 spares skeletal muscle type I to II fiber shift. Cell and Tissue Research 321 233-241.

Moller N, Nielsen S, Nyholm B, Porksen N, Alberti KG \& Weeke J 1996 Glucose turnover, fuel oxidation and forearm substrate exchange in patients with thyrotoxicosis before and after medical treatment. Clinical Endocrinology 44 453-459.

Morte B, Manzano J, Scanlan T, Vennstrom B \& Bernal J 2002 Deletion of the thyroid hormone receptor alpha 1 prevents the structural alterations of the cerebellum induced by hypothyroidism. PNAS 99 3985-3989.

Morte B, Manzano J, Scanlan TS, Vennstrom B \& Bernal J 2004 Aberrant maturation of astrocytes in thyroid hormone receptor alpha 1 knockout mice reveals an interplay between thyroid hormone receptor isoforms. Endocrinology 145 1386-1391.

Motomura K \& Brent GA 1998 Mechanisms of thyroid hormone action. Implications for the clinical manifestation of thyrotoxicosis. Endocrinology and Metabolism Clinics of North America 27 1-23.

Nicol CJ \& Bruce DS 1981 Effect of hyperthyroidism on the contractile and histochemical properties of fast and slow twitch skeletal muscle in the rat. Pflügers Archiv 390 73-79.

Refetoff S 2003 The syndrome of resistance to thyroid stimulating hormone. Journal of the Chinese Medical Association 66 441-452.

Ribeiro MO, Carvalho SD, Schultz JJ, Chiellini G, Scanlan TS, Bianco AC \& Brent GA 2001 Thyroid hormone-sympathetic interaction and adaptive thermogenesis are thyroid hormone receptor isoform-specific. Journal of Clinical Investigation 108 97-105.

Riis AL, Jorgensen JO, Gjedde S, Norrelund H, Jurik AG, Nair KS, Ivarsen P, Weeke J \& Moller N 2005 Whole body and forearm substrate metabolism in hyperthyroidism: evidence of increased basal muscle protein breakdown. American Journal of Physiology. Endocrinology and Metabolism 288 E1067-E1073. dos Santos RA, Giannocco G \& Nunes MT 2001 Thyroid hormone stimulates myoglobin expression in soleus and extensorum digitalis longus muscles of rats: concomitant alterations in the activities of Krebs cycle oxidative enzymes. Thyroid 11 545-550.

Soukup T, Zacharova G, Smerdu V \& Jirmanova I 2001 Body, heart, thyroid gland and skeletal muscle weight changes in rats with altered thyroid status. Physiological Research 50 619-626.

Trost SU, Swanson E, Gloss B, Wang-Iverson DB, Zhang H, Volodarsky T, Grover GJ, Baxter JD, Chiellini G, Scanlan TS et al. 2000 The thyroid hormone receptor-beta-selective agonist GC-1 differentially affects plasma lipids and cardiac activity. Endocrinology 141 3057-3064.

Wahrenberg H, Wennlund A \& Arner P 1994 Adrenergic regulation of lipolysis in fat cells from hyperthyroid and hypothyroid patients. Journal of Clinical Endocrinology and Metabolism 78 898-903. 
White P, Burton KA, Fowden AL \& Dauncey MJ 2001 Developmental expression analysis of thyroid hormone receptor isoforms reveals new insights into their essential functions in cardiac and skeletal muscles. FASEB Journal 15 1367-1376.

Wikstrom L, Johansson C, Salto C, Barlow C, Campos Barros A, Baas F, Forrest D, Thoren P \& Vennstrom B 1998 Abnormal heart rate and body temperature in mice lacking thyroid hormone receptor alpha 1. EMBO Journal 17 455-461.

Withers PC 1977 Measurement of $\mathrm{VO}_{2}, \mathrm{VCO}_{2}$, and evaporative water loss with a flow-through mask. Journal of Applied Physiology 42 120-123.
Yu F, Degens H, Li X \& Larsson L 1998 Gender- and age-related differences in the regulatory influence of thyroid hormone on the contractility and myosin composition of single rat soleus muscle fibres. Pflügers Archiv 437 21-30.

Received in final form 13 December 2006

Accepted 10 January 2007

Made available online as an Accepted Preprint 12 January 2007 